\title{
RAILWAY AND PORTS INTEGRATION SYSTEM AS SOLUTION OF ISLAND TRANSPORTATION PROBLEM (CASE STUDY SUMATRA ISLAND)
}

\author{
Satrio Teguh Amandiri', Okol S Suharyo² \\ Indonesian Naval Technology College, \\ Bumimoro-Morokrembangan, Surabaya 60187, Indonesia
}

\begin{abstract}
The quality of Transportation system is one of island economic level determinant. Railway transportation evidently more efficient than road transportation. Trans-Sumatra railway construction can be a solution for transportation problem in Sumatra Island. This analysis integrated railway and port to improve economic development in 8 provinces on Sumatra using Spanning Tree and Dijkstra algorithm. It need 1965 kilometers of railway to connect all the 8 provinces. It also generates 1518 kilometers as the distance of Malahayati Port to Panjang Port connection. This integrated system can be a breakthrough solution for Sumatra transportation problem in economic development and the Malacca Strait traffic problem.
\end{abstract}

Keywords: Trans-Sumatra railway, Minimum Route, Spanning Tree Algorithm, Dijkstra, Algorithm.

\section{INTRODUCTION.}

Sumatra Island is the world sixth biggest island (Worldatlas, 2018). This island is in the western area of Indonesia archipelago, and known as second most populous island after Java Island (World Population Review, 2018). Administratively, there are 10 Provinces in Sumatra region, with 8 of them in the main island Sumatra. These Provinces consist of Nanggroe Aceh Darussalam, North Sumatra, West Sumatra, Riau, Jambi, Bengkulu, South Sumatra, and Lampung. Economically, Sumatra Island has potential to be developed as a national plantation area and industrial corridor to support national economic (Berawi, et al., 2017).

Sumatra Island has mine deposit especially crude oil, coal, bauxite and lead that spread in almost of all provinces (Leeuwen, 2014). Sumatra's natural geography with stretched rows of mountains and hills from north to south give soil fertility that utilized for plantation especially tobacco, coffee and palm oil (Quincieu, 2015) (Maat, 2014) (Euler, et al., 2015). Beside of that advantage, in opposite, contour difference of land surface creates transportation problem on the island. Planning of road geometric design must adjust the land contour and cannot take the straight line between cities (Ragab, 2016). This situation makes swell in road infrastructure building cost and long distance intercity as the result (Lee, 2015).

One of solutions proposed to solve this transportation problem is building railways. Generally, train transport has 3 advantages compared to road transport; first is speed, safety and efficiency of fuel usage. The train has its own lines that didn't share with another transport system. The train also consumes fuel more efficiently in material than truck and another road carrier (Tolliver, et al., 2013). The second, railway construction gives better long-term effect in increase economic area growth (de Rus, 2008). Bigger initial investment than road construction will be covered by economic activities increase creates by railway ( $\mathrm{Wu}$, et al., 2016). The last advantage is integration easiness between railway and freight facilities in port. Main ports in Sumatra, in example Kuala Tanjung Port, are the starting point and end 
point from cargo freight circulation. Cargo sized freight will be easily moved using the train (Lewis, 2017). This convenience shall speed up freight distribution and encourage economic activities, especially in Sumatra Island (Hlača, et al., 2010).

Trans-Sumatra railway construction involves massive initial investment (Baumgartner, 2001) (Gattuso \& Restuccia, 2014). This project needs correct planning so will produce optimum results (Spang, 2002) (Bast, et al., 2016). Trans-Sumatra railway must meet 2 criteria, first it connects all capital provinces. The railway that consumes big fund on investment will be projected as a main transport system in Sumatra Island (Lingaitis \& Sinkevičius, 2014). Second criterion, TransSumatra railway shortest distance option from Banda Aceh to Bandar Lampung. This route expected as a solution to reduce heavy traffic in Malacca Strait (Ibrahim \& Khalid, 2007) (Zaman, et al., 2015). Trans-Sumatra railway route determined by Spanning Tree Method and Dijkstra Algorithm Method. Shortest route given by these combined methods creates benefit as a smaller construction cost and optimum coverage range. Railway construction takes into consideration of port location as the main point of freight expedition. Railway integration with ports increase economic sector in Sumatra Island.

\section{MATERIALS AND METHODS.}

In this article, analysis will be conducted to determine optimum Trans-Sumatra railway route in notice:

1. Existing railway route in Sumatra Island can utilized as part of Trans-Sumatra railway route.

2. Provinces with international port and main national port will be starting and end point for Trans-Sumatra railway route.
3. Trans-Sumatra railway route integrated 8 capital provinces in Sumatra Island.

\subsection{Transportation infrastructure in Sumatra Island}

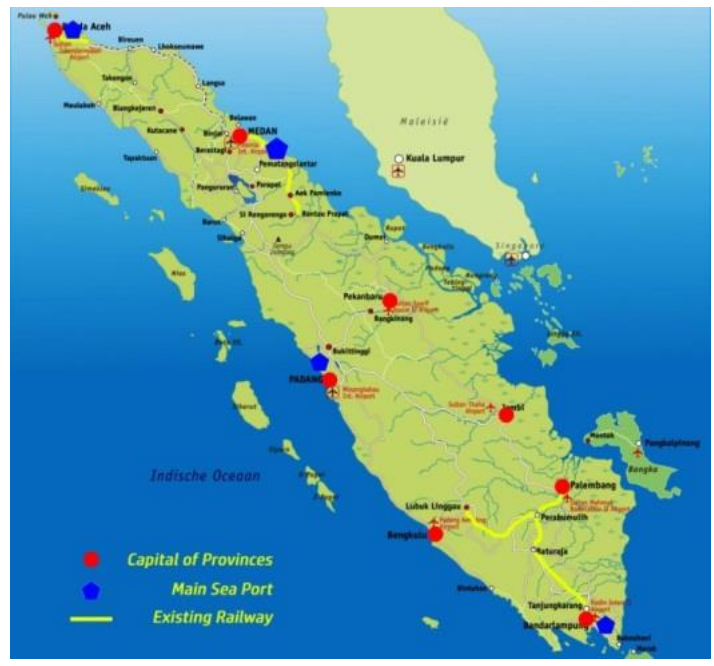

Fig. 1 Sumatra's Capital Provinces and

Transportation infrastructure

From figure 1 , there are 1 International port and main national ports in Sumatra Island as the part of Indonesia's Sea Toll Road Program. These ports that proposed as export and import corridor for cargo freight are Kuala Tanjung Port, Malahayati Port, Teluk Bayur Port and Panjang Port.

Sumatra Island already had 2 railway systems former of mining and plantation transport. These railways are:

North Area: connecting Binjai, Belawan, Medan, Kualanamu, Kisaran until Rantau Prapat.

South Area: connecting Tanjung Karang, Kotabumi, Martapura, Baturaja, Prabumulih, Muaraenim, Tebingtinggi and Lubuk Linggau

Today, capital provinces on Sumatra Island connected by roads, with distance as mention in table 1. 
Table 1. Distance between Capital Provinces on Sumatra Island (in Kilometers).

\begin{tabular}{|c|c|c|c|c|c|c|c|c|}
\hline & $\begin{array}{c}\text { Banda } \\
\text { Aceh }\end{array}$ & Medan & Padang & Pekanbaru & Jambi & Palembang & Bengkulu & $\begin{array}{c}\text { Bandar } \\
\text { Lampung }\end{array}$ \\
\hline Banda Aceh & & 601 & 1230 & 1272 & 1725 & 2006 & 1776 & 2278 \\
\hline Medan & 601 & & 751 & 655 & 1111 & 1392 & 1437 & 1846 \\
\hline Padang & 1230 & 751 & & 311 & 518 & 756 & 550 & 1111 \\
\hline Pekanbaru & 1272 & 655 & 311 & & 459 & 735 & 771 & 1181 \\
\hline Jambi & 1725 & 1111 & 518 & 459 & & 280 & 448 & 669 \\
\hline Palembang & 2006 & 1392 & 756 & 735 & 280 & & 437 & 369 \\
\hline Bengkulu & 1776 & 1437 & 550 & 771 & 448 & 437 & & 568 \\
\hline $\begin{array}{c}\text { Bandar } \\
\text { Lampung }\end{array}$ & 2278 & 1846 & 1111 & 1181 & 669 & 369 & 568 & \\
\hline
\end{tabular}

\subsection{Dikjstra Algorithm}

Founded by Edgar Wybe Dijkstra in 1956, this algorithm executed by greedy principal. Unchosen minimum weight node connected with chosen node. Dijkstra algorithm calculate shortest path from end to end with lowest weight connection (Javaid, 2013).

In this analysis, Dijkstra algorithm use for defining minimum route to connect Banda Aceh and Bandar Lampung as represent Malahayati Port and Panjang Port (Likaj \& Shala, 2017). This connection created to speed up goods and cargo carriage as support of Sabang International Hub development plan. International cargo unloaded in Sabang Port will be distributed to entire Indonesia via Panjang Port in Bandar Lampung. Vice versa, Panjang Port role as feeder for Sabang Port to collect all of export cargo from whole country (Wang, et al., 2014). Trans-Sumatra railway will be connector for this cycle.

\subsection{Spanning tree}

Another routing system, a tree identified as spanning tree if (Vikash, 2010):

- Contains all the original graph's vertices

- Reaches out to (spans) all vertices.

- acyclic or the graph doesn't have any nodes which loop back to itself.
Generally, 2 algorithms use in Spanning Tree method, Kruskal algorithm and Prim algorithm (Arogundade, et al., 2011) (Li, et al., 2017). Spanning tree concept in this analysis create network connection of 8 capital provinces. Using this network connection, inter cities movement of goods and human will be faster (Akpan \& Iwok, 2017).

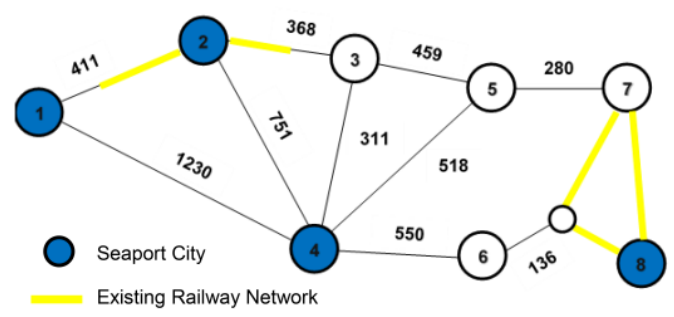

Fig. 2 Graph Network of inter capital provinces distance (in kilometers).

From figure 2 above, shortest integrated route calculation using Spanning Tree and Dijkstra Algorithm must pay attention on ports location as end of transport process. There are 2 priorities for shortest route calculation; first is connecting nonport capital provinces with port-facilities capital provinces. Second priority is to shorten Malahayati Port - Panjang Port route.

\section{RESULTS.}

Minimum distance calculation using Spanning Tree Method and Dijkstra Method gain result as in table 2.

Table 2. Calculation and result of shortest railway network

\begin{tabular}{|c|c|c|c|c|c|c|c|c|c|c|}
\hline Unvisited & Visited & & 1 & 2 & 3 & 4 & 5 & 6 & 7 & 8 \\
\hline$\{1,2,3,4,4,6,6,7,8\}$ & $\{6\}$ & & $(\sim-i)$ & $(0,-)$ & $\left(\sim_{i}\right)$ & $(0,-)$ & $\left(v_{i}\right)$ & $\left(\sim_{i}\right)$ & $(0 ;)$ & $(0,-)$ \\
\hline$\{1,2,3,4,5,6,6\}$ & $\{7,8\}$ & 7 & $(\sim-i)$ & $\left.(0,)^{2}\right)$ & $\left(\tilde{n}_{i}\right)$ & $(0,-)$ & $(280,-)$ & $(136,-)$ & & \\
\hline$\{1,2,3,4,4\}$, & $\{6,7,8\}$ & 6 & $(\sim ;)$ & $(0,-)$ & $\left(\sim_{i}\right)$ & $(550,-)$ & $(280,-)$ & & & \\
\hline$\{1,2,3,4\}$ & $\{5,6,7,8\}$ & 5 & $(\sim ;)$ & $(0,-)$ & $(459,-)$ & $(518,-)$ & & & & \\
\hline$\{1,2,4\}$ & $\{3,5,6,7,8\}$ & 3 & $(\sim ;)$ & $(368 ;-)$ & & $(311,-)$ & & & & \\
\hline$\{1,2\}$ & $\{3,4,5,6,7,8\}$ & 4 & $\left(411 i_{;}\right)$ & $(368,-)$ & & & & & & \\
\hline$\{1\}$ & $\{2,3,4,4,6,6,7,8\}$ & 2 & $(411,-;)$ & $(368 ;)$ & & & & & & \\
\hline\{\} & $\{1,2,3,4,5,6,6,7,8\}$ & 1 & & & & & & & & \\
\hline
\end{tabular}




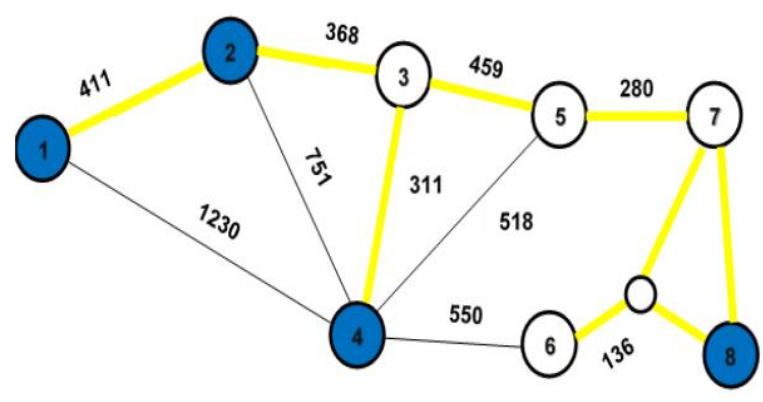

Fig. 3 Graph connection railway network in Sumatra Island

From figure 3, railway network as analysis result generate shortest route connected Malahayati Port and Panjang Port is along 1518 kilometers. This route pass through Medan, Pekanbaru, Jambi and Palembang. Shortest path that integrate all of capital provinces in Sumatra Island is need 1965 kilometers railway. Padang directly connect to Pekanbaru, and Bengkulu connect to Palembang and Bandar Lampung via Lubuk Linggau. The implementation of the railway as in figure 4 .

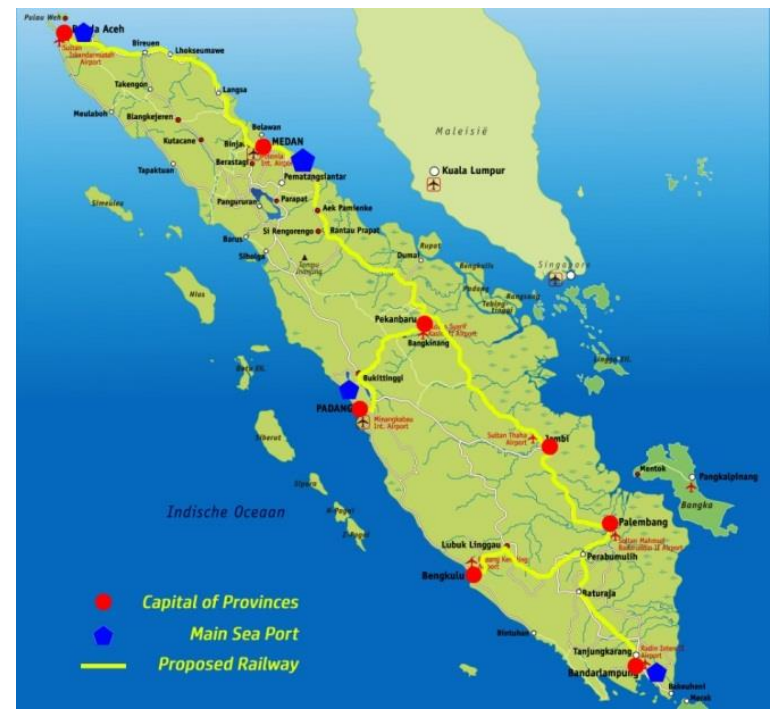

Fig. 4 Trans-Sumatra railway implementation based on minimum route analysis

\section{DISCUSSION.}

Trans-Sumatra railway will be a breakthrough solution in transportation system problem on Sumatra Island. Ports development to be International and main national ports based on the
Sea Toll Road Program can synergize with TransSumatra railway. This railway construction would stimulate economic growth, especially in Sumatra Island.

Consider the massive investment cost needed to support this project, the government should divide it into several development plans. There are 2 priority option can be chosen, first is creating an inter capital provinces connection. The second is finishing Malahayati Port - Panjang Port connection as the solution for Malacca Strait Traffic.

The Trans-Sumatra railway analyzed in this paper follow the existing road path on Sumatra Island. It uses gross distance based on inter capital provinces distance data. Need advanced analysis mainly in geographic aspects to create shorter route that can economize construction budget.

\section{CONCLUSION}

Trans-Sumatra railway construction will speed up goods distribution in Sumatra Island. This project can enhance economic sector as impact of reduced delivery time of mining products, plantation products and cargo freight. Integration with Sea Toll Road Program; ports development and Sabang Port development plan as International Hub will increase the benefit value of Trans-Sumatra railway. Last, the Trans-Sumatra railway can provide people in Sumatra Island a cheap and safe long-distance transportation.

\section{BIBLIOGRAPHY.}

Bast, H. et al., 2016. Route planning in transportation networks. Algorithm engineering, pp. 19-80.

Baumgartner, J. P., 2001. Price and Cost in The Railway Sector. Lausanne: École Polytechnique Fédérale de Lausanne - Laboratoire d'Intermodalité des Transports Et de Planification. 
Berawi, M. A., Miraj, P. \& Sidqi, H., 2017. Economic corridor of industrial development in Indonesia. IOP Conference Series: Earth and Environmental Science, Volume 109.

de Rus, G., 2008. The economic effects of high speed rail investment. Paris: OECD - International Transport Forum.

Euler, M., Schwarze, S., Siregar, H. \& Qaim, M., 2015. Oil palm expansion among smallholder farmers in Sumatra, Indonesia, Göttingen: Universität Göttingen.

Gattuso, D. \& Restuccia, A., 2014. A tool for railway transport cost evaluation. Procedia - Social and Behavioral Sciences, Volume 111, p. 549 - 558.

Hlača, B., Rudić, D. \& Hirnig, S., 2010. Rail Transport - An Important Factor in The Port of Rijeka Development. Promet Traffic\&Transportation, 22(5), pp. 379-388.

Ibrahim, H. M. \& Khalid, N., 2007. GROWING SHIPPING TRAFFIC IN THE STRAIT OF MALACCA : SOME REFLECTIONS ON THE ENVIRONMENTAL IMPACT. Singapore, Maritime Institute of Malaysia.

Lee, J., 2015. Road Infrastructure: The Challenge for Indonesia. Jakarta, Australian Aid.

Leeuwen, T. v., 2014. A Brief History of Mineral Exploration and Mining in Sumatra. Palembang, ResearchGate, pp. 35-57.

Lewis, R., 2017. Connecting Communities through Port and Rail Planning, Johannesburg: Transnet.
Lingaitis, V. \& Sinkevičius, G., 2014. Passenger transport by railway: evaluation of economic and social. Procedia - Social and Behavioral Sciences, Volume 110, pp. 549-559.

Maat, H., 2014. Agriculture in Indonesia, Dordrecht : Encyclopaedia of the History of Science, Technology, and Medicine in Non-Western Cultures.

Quincieu, E., 2015. SUMMARY OF INDONESIA'S AGRICULTURE, NATURAL RESOURCES, AND ENVIRONMENT SECTOR ASSESSMENT, Manila: Asian Development Bank.

Ragab, O., 2016. Introduction for Geometric Design of Highways. s.I.:s.n.

Spang, K., 2002. Project management and railway construction. s.I.:IPMA Congress.

Tolliver, D., Lu, P. \& Benson, D., 2013. Comparing rail fuel efficiency with truck and waterway. Transportation Research Part D, Volume 24, p. 6975.

World Population Review, 2018. Indonesia Population 2018. [Online] Available at: http://worldpopulationreview.com/countries/indonesi a-population/

Worldatlas, 2018. Islands of The World. [Online] Available at: https://www.worldatlas.com/aatlas/infopage/islands. $\underline{\mathrm{htm}}$

Wu, W., Liang, Y. \& Wu, D., 2016. Evaluating the Impact of China's Rail Network Expansions on 
Local Accessibility: A Market Potential Approach. Sustainability, 8(512).

Zaman, M. B., Kobayashi, E. \& Wakabayashi, N., 2015. Risk of Navigation for Marine Traffic in the Malacca Strait using AIS. Procedia Earth and Planetary Science, Volume 14, pp. 33-40. 